\title{
ON THE ECONOMIC THOUGHT OF TRADE PRACTICES AND POLICIES IN KENYA ${ }^{\circ}$
}

\author{
EL PENSAMIENTO ECONÓMICO DETRÁS DE LAS PRÁCTICAS \\ Y POLÍTICAS COMERCIALES EN KENIA
}

\author{
Socrates Kraido Majune* \\ Davis Kimuli Mwania**
}

enviado: 13 agosto 2020 - aceptado: 26 noviembre 2020

\begin{abstract}
This study explains trade regimes in Kenya from a History of Economic Thought (HET) perspective using secondary materials (books, papers, and original manuscripts). We found that the pre-colonial era (before 1895) had a mixture of Classical doctrines and Mercantilism, whereby long-distance and barter trade between communities were practiced. Nonetheless, certain communities restricted trade. Classical economic thought was practiced in the colonial period (1895-1962), whereby agricultural produce was exported and less expensive consumables were imported. The post-colonial period started with a Mercantilism approach (Importsubstitution), but successive regimes have promoted Classical doctrines of trade by reducing import and export barriers and creating trade-promotion institutions. Trade in services, which is topical in international trade, has also been promoted in this regime.
\end{abstract}

JEL Codes: B10, B17, B20, B27.

Keywords: history of economic thought, trade reforms, Kenya.

Majune, S. K., \& Mwania, D. K. (2021). On the economic thought of trade practices and policies in Kenya. Estudios económicos, 38(77), pp. 187-205. DOI: https://doi.org/10.52292/j.estudecon.2021.2256.

* University of Nairobi, Kenya. ORCID: https//orcid.org/0000-0002-4740-7284.

E-mail: skmajune@uonbi.ac.ke

** University of Nairobi, Kenya. ORCID: https://orcid.org/0000-0001-9163-5113.

E-mail: mwaniadavis@gmail.com 


\section{Resumen}

Este estudio explica los regímenes comerciales en Kenia desde una perspectiva de la Historia del Pensamiento Económico (HPE) utilizando fuentes secundarias de información (libros, artículos y manuscritos originales). Se concluye que durante la era precolonial (antes de 1895) sobre la base de la conjunción de las doctrinas clásicas y el mercantilismo, se practicaba el comercio a distancia y el trueque entre comunidades. No obstante, algunas comunidades restringieron el comercio. Durante el periodo colonial (1895-1962), fundado en el pensamiento económico clásico, se exportaban productos agrícolas y se importaban consumibles menos costosos. El período poscolonial comenzó con un enfoque mercantilista (sustitución de importaciones), pero los sucesivos regímenes han promovido las doctrinas clásicas del comercio reduciendo las barreras a la importación y exportación e instaurando políticas de promoción comercial. Este régimen también promovió el comercio de servicios, que es una temática de interés actual en el comercio internacional.

Códigos JEL: B10, B17, B20, B27.

Palabras clave: historia del pensamiento económico, reformas comerciales, Kenia. 


\section{INTRODUCTION}

This study traces trade reforms in Kenya from the History of Economic Thought (henceforth, HET) perspective. The subject of HET is in limbo with a strand of proponents (Kurz, 2006; Kates, 2013; Aspromourgos, 2017; Lapidus, 2019; Bögenhold, 2020) and opponents (Blaug, 2001) regarding of its relevance in Economics. Nevertheless, it has remained canonical (Lapidus, 2019). What follows is a proof(s) that HET is not abstract and teleological, but very much alive in real-life. This is the main objective of this study.

We undertook this exercise by tracing the development of trade reforms in Kenya. Kenya was used as a case study for several reasons. Foremost, the country has undergone several episodes of trade policies as will be seen in the forthcoming sections. The episodes are varied, at some point autarky was practiced and, lately, liberalization is pursued. Thus, this is one reason making Kenya apt for this task. Autarky is related to the mercantilist policies that advocated for import restrictions and a boost in exports to ensure a favorable balance of trade (Landreth \& Colander, 2002). This would in turn increase the stock of bullions (gold, silver, and other precious metals). Thomas Mun, William Petty, David Hume, Richard Cantillon, and Bernard Mandeville are acknowledged to advance mercantilist ideas and thoughts that served as precursors to the classical school of thought (Landreth \& Colander, 2002).

Other mercantilist doctrines that are associated with autarky, such as stateled protectionism, were also shared by Friedrich List of the Older Historical School of economic thought. Through his publication of 1841, The National System of Political Economy, List advocated for state-led protectionism so as to protect infant industries of under-developed countries. On the other hand, Karl Marx of the Marxian school viewed capitalism as exploitative of labor (proletariats) (Landreth \& Colander, 2002). Juxtaposing this to international trade, Karl Marx posited that the liberal notion that free trade facilitates the interests of all nations in harmony overlooks inequality, exploitation, and domination of the bourgeoisies over the proletariats stimulated by the international division of labor (Coulomb \& Bellais, 2008). Marxists such as Lenin and Luxemburg asserted that the complexities within capitalist economies eventually lead to conflict and wars, which signify the culmination of the capitalist manner of production (Coulomb \& Bellais, 2008). Free trade has led to the rise of global corporations, especially from developed countries, that benefit at the expense of their less-developed partners (Strange, 2020). 
Liberalization or openness supports free trade. It is associated with scholars of the Classical school of economic thought, Adam Smith and David Ricardo. Through his 1776 book, An Inquiry into the Nature and Causes of the Wealth of Nations, Adam Smith stated that countries should export commodities with which they have absolute advantage and import those in whom they have absolute disadvantage. David Ricardo envisioned trade as beneficial to countries when considering their comparative advantage in producing goods (Ricardo, 1817). A country might have absolute advantage in producing several commodities compared to its partner, but they can trade in view of their respective opportunity costs (comparative production costs).

The second reason for basing this study on Kenya is because it is among the top exporters of both goods and services in Sub-Saharan Africa (SSA). According to Figure 1, Kenya's rank in exports of goods in Sub-Saharan Africa has oscillated between position 9 and 13 over the period of 1960 and 2019. The performance has been stellar for services where Kenya has ranked among the top three in the region. Based on these statistics, we conjectured that Kenya is one of the trade superstars within the region, thereby begging the question of the economic thought behind respective trade policies over time.

Several theories have emerged following the works of Smith and Ricardo to explain international trade. The Heckscher-Ohlin theorem (developed in 1919 and 1933, respectively) states that trade between countries occurs due to differences in their relative factor endowments (Geda, Fundamentals of International Economics for Developing Countries: A Focus on Africa, 2012). New Trade Theories (NTT) emerged between the 1960s and the early 1990s to explain trade through technological gaps (Posner, 1961; Vernon, 1966; Gruber, Mehta, \& Vernon, 1967), and imperfect competition and product differentiation (Lancaster, 1966; Dixit \& Stiglitz, 1977; Krugman, 1979; Lancaster, 1980; Krugman, 1980; Falvey, 1981; Helpman, 1981; Ethier, 1982; Brander \& Krugman, 1983; Krugman, 1991). The New New Trade Theories (NNTT) started in 1995 with the seminal work of Bernard and Jensen (1995) and were later advanced by Bernard and Jensen $(1999,2004)$, Melitz (2003), Bernard et al. (2003), and Yeaple (2005). These theories explain international trade using firm-level data, hence forming micro-level stylized facts.

Thirdly, this study advances the literature on the history of economics, which is beneficial to HET practitioners. Especially, to students who crave for the practical side of the subject. Similarly, practitioners in Sub-Saharan Africa stand to benefit from this, since most of the literature in the region is on economic history (Moradi, 2018), which deals with the past economic aspects of societies, as opposed to the history of economic thought, which is concerned with the past economic ideas (Bögenhold, 
2020). Generally, this study enriches HET discussions by incorporating heterodoxies of the International Trade theory, such as trade in services and firm-level trade theory.

Figure 1. Ranking of Kenya's Exports of Goods and Services in Sub-Saharan Africa from 1960 to 2019

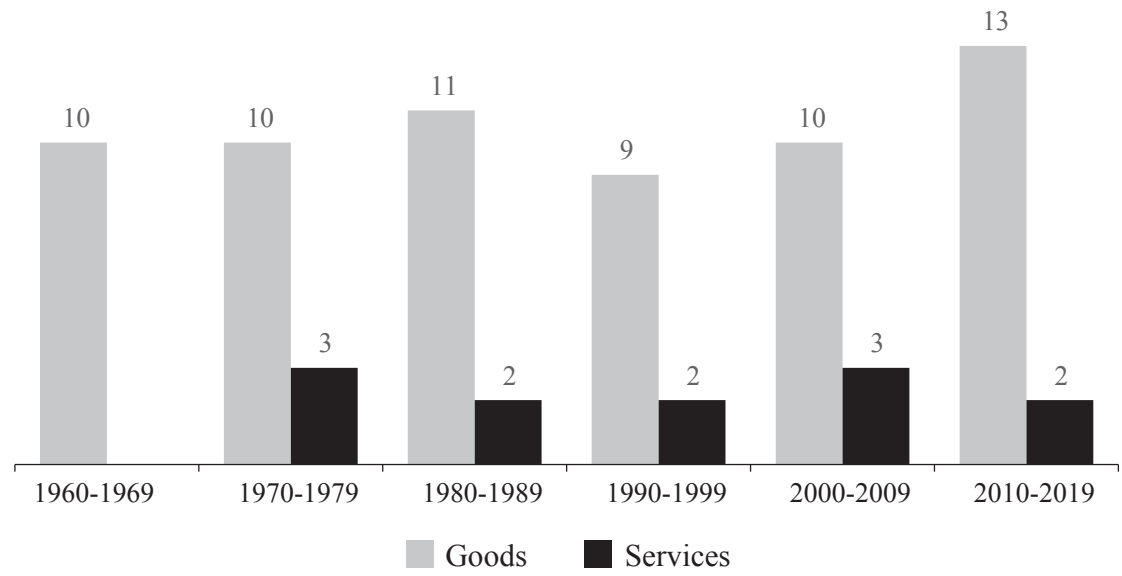

Source: Author's computation using WITS (for goods) and WDI (for services) databases.

In brief, Kenya's trade reform has undergone three eras: pre-colonial era, colonial era, and post-colonial era. The next sections of this paper explain the economic thought of each period and ends with the conclusion.

\section{PRE-COLONIAL ERA (BEFORE 1895)}

There is a considerable extensive history of a cohesive and independent economic activity in many regions of Africa with indigenous and long-distance trade connecting the continent. Africa thrived in an economic autonomous system that was fair and just even prior to the colonial imperialism and slavery that imposed underlying dealings with Europe (Geda, 2019). A rich diversity in agricultural products, a range of processed commodities, and a broad natural resource base characterized and distinguished the African internal trade. In Kenya, during the eighteenth and nineteenth century, apart from barter trade among communities, long-distance trade was practiced among the Mijikenda, Kamba, Taita, and Waata with the Swahili, Arabs, and the Waata across the coastal line of the Indian Ocean (Van Zwanenberg \& King, 1975; Ndege, 1992a, 1992b). 
No formal trade policy existed at the time due to decentralization of the communities and lack of a sovereign rule that could impose one overall policy. Rather, communities existed cohesively, and trade took place through the barter trade. The assumption that the economy works like a barter system has been taken into account explicitly in classical principles and, implicitly, in neoclassical principles. Classical scholars such as Adam Smith, David Ricardo, Jean Baptiste Say supported the real ratio of interchange, but still asserted that the barter illusion is necessary in affirming their principles. For instance, Ricardo reduced the effect of money and conceded that in order to debunk Malthus' proposition that general overproduction is unattainable, Say's barter illusion is indisputable (Dillard, 1988).

Regions exchanged their goods for others that they did not have, thereby gaining an absolute advantage in the sense that supplied goods were less expensive than those they could possibly produce themselves (Schumacher, 2012). For instance, the Mijikenda exchanged coconut and coconut products for vegetables, livestock, and grains from the Kamba, Taita, and Waata as the Swahili Arab and Indian traders brought salt, cotton cloth, jewelry, and other manufactured goods (Herlehy, 1984). Similarly, trade took place because of the varying different levels of comparative advantage of communities and regions. Areas that were relatively more productive in certain goods compared to others had a rationale for exchanging these goods to obtain those in which they were relatively less productive in. The classical school of thought clearly was present within the pre-colonial Kenyan context.

The mercantilist ideal of wealth accumulation was also present among the East African communities as trade was a chief origin of wealth. Simply put, there was profit gained from trade and even among non-stratified communities, like the Kikuyu and Maasai in Kenya that had an indirect system of rule exchange of agricultural produce for cattle, respectively, and this was actively carried out. Localized trade was fueled by the variations in the economic activities in the different regions, creating an economic symbiosis. This is exemplified by the Gusii-Luo trade, where the latter exchanged grain for meat. On the other hand, foreign trade along the coastal Kenya primarily involved the Akamba traders, who hunted for ivory to obtain international goods like salt and metals (Van Zwanenberg \& King, 1975).

\section{COLONIAL ERA (1895-1962)}

Nzula, Potekhin, and Zusmanovich (1979) and Amin (1972) demarcated Africa into three regions depending on the structure of colonialism: 'Africa of the labor reserves' as Eastern and Southern Africa, 'Africa of the Colonial economy' as 
British and French West Africa, and 'Africa of the concession-owning companies' as the Belgian Congo and French Equatorial Africa. Kenya fell in the first category. During the colonial era, export of primary goods from the white settler's farmers and minerals from the European controlled ores formed much of the trade. A commodity exporting economy and a dominion over both African exports and imports by the colonial powers was the aftermath of a cruel colonial period. This helped build the strength of the colonial powers since they had a huge resource base: both human and capital resources including natural capital such as trees, minerals, and precious metals at their disposal.

Van Zwanenberg and King (1975) noted that as the dominance of the colonial government grew, so did the African trade. This could be attributed to the central direct rule that facilitated easier and safer movement of both goods and traders owed to the developing railway. This drastically changed the emphasis of Kenyan trade from domestic to international trade, where local agricultural produce would be exported, and less expensive consumables, imported. However, African traders were sidelined in this new wave of trade, while the Indian traders took advantage of the railway line, installed 'dukas', which means shops at central trading locations such as Voi, Machakos, Kibwezi, and at most, if not all, military posts.

Whereas the colonial government encouraged the growth of African enterprises in the early 1930s, their enterprises did not expand due to European and Asian dominance. Africans also lacked credit and credible experience, but managed to trade on a smaller scale. In the mid-1930s, the colonial government put restrictions such as licenses to limit and regulate the multitude of traders as well as decrease competition between them. Hurdles that kept Africans aloof from trade and the profit thereof persisted even in the 1950s. This led to a rise in the level of agitation among the Africans, and Europeans began to support African traders. This was arduous, as the Indians had already monopolized not only the local trade, but also the international one of exports and imports. As a result of the support by the British colonial authorities, trade attracted many since it was deemed gainful. Nevertheless, the ratio of small-scale African traders to the number of people increased, and the dominance of the Asian traders in the major towns, even in the wake of independence, was quite prevalent (Van Zwanenberg, \& King, 1975).

Clearly, the notions of mercantilism and classicism of the creation and building of strong nations through bullionism and wealth accumulation were at play, governing the era of colonialism. 


\section{POST-COLONIAL ERA - KENYA AS A REPUBLIC (1963 TO DATE)}

Kenya has undergone five major trade regimes since attaining independence in 1963 (see Figure 2). First, the country practiced import substitution between 1963 and 1979 in accordance with the Sessional Paper No. 10 of 1965 (Nyaga, 2015). This entailed suppressing the amount of imports in the country, mainly in the manufacturing sector, through tariffs. The country also signed a few trade agreements: the General Agreement on Tariffs and Trade (GATT) in 1964 and the East African Community (EAC) in 1967, although it collapsed in 1977.

Generally, this trade regime was highly protectionist and encouraged the growth of infant industries with the aim of increasing to match global standards. This could have been highly motivated by the idea that holding the right of control over economic forces as a way to economic independence would further assure the country of its political independence that had just been gained from the British colonial government. This notion of nationalism and protectionism dates to the preclassical era of mercantilism that fueled colonialism. It is interesting to note that the same economic thought that supported economic nationalism during colonialism was now a double-edged sword being used as a rationale to build and protect the young Republic of Kenya. The country at this point in time was concerned with gaining a positive balance of payment, fostering nationalism, strictly regulating imports, and attaching the central role of governing economic opportunities to the state, all of which heavily hinge on this pre-classical notion. David Hume, one of the key influential pre-classical economists, noted that industry "would not emerge spontaneously, it would have to be induced by legislation." This is precisely what the young Kenyan government was considering in establishing and facilitating state corporations and infant industries with the laissez-faire notion being thrown in the basket (Skinner, 1993).

The second export regime pursued by Kenya was the Structural Adjustment Policies (SAPs), which lasted between 1980 and 1992. This was guided by the Session Paper No.1 of 1986 on Economic Management for Renewed Growth, which advocated for export promotion. SAPs were necessary due to the persistent economic instability arising from economic shocks, such as increases in oil prices, the fall in the commodity prices, and the disintegration of the then budding East African Community. Breton Woods institutions, the World Bank, and the International Monetary Fund (IMF) were the key architects of this policy. 
Figure 2. Flow of Trade Regimes under the Post-Colonial Era in Kenya

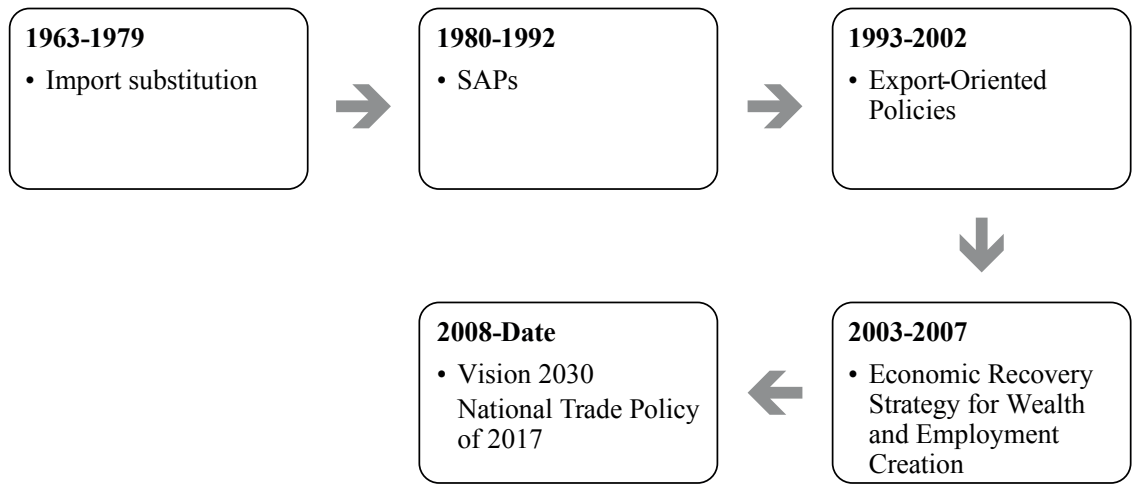

Source: Author's compilation.

SAPs supported privatization of public agencies and liberalization of trade across borders (Gertz, 2008). The concept of laissez faire, that dates back to Physiocrats, aimed at removing the government regulation or minimizing any other form of government interference in the economy. It was based on the conviction that, devoid of the government, the natural order yields the common good for all. It is worthwhile to note that Adam Smith was moderate regarding the laissez faire argument, since he envisaged the role of government and advocated for British protectionism and imposition of prohibitions on foreign shipping under the Navigation Acts (Walter, 1996). Whether the laissez faire argument was 'soft' or 'hard', as espoused by the Neoclassicists, remains to be quite contentious (Henry, 2008). It is possibly on the bias of the laissez faire argument, especially by the dominating New Classical School of economic thought, that the IMF and the World Bank advocated for minimum state regulation and this saw the beginning of the era of trade liberalization. Trade liberalization advocates for reduced regulation of crossborder flows of goods and services among countries through abolishment of tariff and non-tariff barriers to trade (Omolo, 2011).

SAPs incorporated import liberalization policies, such as replacing import tariffs by quotas, reducing tariff levels, and relaxing foreign exchange restrictions. Exports were promoted through the reduction of tariff rates and duties on final products and industrial inputs, the introduction of Manufacturing under Bond (MUB) in 1988, the establishment of Export Processing Zones (EPZs) in 1990, the creation of the Export Promotion Council (EPC) in 1992, the revival of the Kenya Export Trade Authority, and the introduction of export Guarantee and Credit Scheme and duty 
and the Value Added Tax (VAT) exemption scheme for exporters (Were et al., 2002; Nyaga, 2015). Kenya also joined the Preferential Trade Area (PTA) in 1981 and the Intergovernmental Authority on Drought and Development (IGADD) in 1986.

The above policies are mainly based on the role of trade as explained by Smith and Ricardo in their Absolute and Comparative Advantage theories. The creation of trade promotion institutions, such as EPZs, is linked to the HeckscherOhlin (H-O) theorem. This theorem predicts that trade between countries is promoted by differences in their factor endowments. Intuitively, this can be real factor endowments, quality of domestic institutions or domestic labor market institutions (Sauvé \& Roy, 2016). Hence, the establishment of strategic institutions like EPZs was meant to make Kenya competitive by having better-functioning institutions. This falls within the realm of H-O theorem. The New New Trade Theory (NNTT) was also advanced under this regime whereby policies were formed targeting trading firms. For instance, firms that participated in the EPZs were offered tax holidays, tariff waivers for their imports, and were treated as exceptions regarding many business regulations. The Export Promotion Programmes Office (EPPO), which was established in 1993, was open to both to both fully and partially exporting firms and provided refunds for taxes paid on imports for inputs necessary for production (Nyaga, 2015).

The third regime was a period of openness that lasted between 1993 and 2002. The guiding policy document for this regime was the Sixth Development Plan (1989-1993). According to Wacziarg and Welch (2008), Kenya liberalized in 1993. Therefore, during this regime, trade was promoted through the formation of the National Export Credit Guarantee Coorporation, the cancelation of export duties, the introduction of export retention schemes, the restructuring and reduction of tariffs, and the 100\% retention of foreign exchange earnings by exporters in 1993 (Gertz, 2008). In addition, EAC was revived in 1999, PTA was replaced by the Common Market for Eastern and Southern Africa (COMESA) in 1994, and Kenya joined the African Growth and Opportunity Act (AGOA) and the Indian Ocean RIM Association (IORA) in 2001 and 1997, respectively. The IGADD was also replaced by the Intergovernmental Authority on Development (IGAD) in 1996, and Kenya joined the World Trade Organization (WTO) in 1995.

The fourth export regime is linked to the Economic Recovery Strategy for Wealth and Employment Creation (ERS) (2003-2007). Through this regime, Kenya established a National Export Strategy in 2004 and was among the signatories of the EAC Customs Union in 2005. AS a result, it benefited from a Common External Tariff (CET) that was established by EAC members. 
The fifth export regime, from 2008 to date, is guided by the Vision 2030 and the National Trade Policy of 2017. Vision 2030 is Kenya's development plan that aims at tranforming the country to a middle-income status by 2030 (ROK, 2007). Conversely, the National Trade Policy was introduced in 2017 to guide Kenya's trade strategy at a domestic and international level (ROK, 2017). Through this period, Kenya has promoted international trade in three ways. First, Kenya joined a number of reginal trade agreements. For instance, the Economic Partnership Agreements (EPAs) in 2016, the COMESA-EAC-SADC Tripartite Free Trade Area (TFTA) in 2015, and the African Continental Free Trade Area (AfCFTA) in 2018 (ROK, 2017). AfCFTA is the largest Free Trade Area (FTA) in the world after the creation of the WTO (Obeng-Odoom, 2020). Kenya was also a signatory to the EAC Common Market Protocol in 2010. Second, Kenya has established bilateral trade agreements with several partners. So far, Kenya has thirty-six bilateral trade agreements (ROK, 2017) of which ten have been ratified after $2005^{1}$. Lastly, Kenya has adopted concerete policy making processes through introducing, implimenting, and assessing key tradeenhancing strategic plans besides involving more stakeholders in the promotion of international trade. Along with the National Trade Policy, other key policy documents have been launched and implimented after 2008. For instance, both the 2009-2013 and the 2014-2019 Strategic Plans of the EPZs suggested the establishment of a one stop border post with neighbors to enhance trade facilitation. Several one stop border posts have been established with Uganda and Tanzania between 2016 and 2018. The 2013-2017 Strategic Plan of the Ministry of Indurstrialization and Enterprise Development has also suggested ways to enhance the private sector, especially the Small and Medium Enterprises (SMEs) for their contribution to international trade.

Both the third and fourth regimes advocated for trade, thereby abiding by classical creeds of Smith and Ricardo and subsequent trade theories. However, the fifth regime has been more concrete in policies that promote and hinder trade. Thus mixing pre-classical, classical, and post-classical doctrines. The three aforementioned trade promotion schemes (in the fifth regime) are in line with the classical, new trade, and new new trade theories. The policies target country-level characteristics, such as the trade policies to be pursued and firm-level features targeting exporters and importers. We believe that the current regime also targets promotion of trade in services through the National Trade Policy of 2017 and respective trade agreements.

Services first appared in international trade through the General Agreement on Trade in Services (GATS) of 1995. Due to their nature of intangibility and non-sto-

1 Libya (2007), South Africa (2008), China (2011), Ethiopia (2010), Nigeria (2014), Sri Lanka (2013), Ghana (2014), Republic of Sudan (2015), Israel (2016), and Jordan (2016). 
rability, classical theories considered services to be non-tradable ${ }^{2}$. However, the role of services in international trade has grown and they currently account for about $25 \%$ of global exports (Loungani, Mishra, Papageorgiou, \& Wang, 2017). This incidence is higher in countries like Kenya, where services currently account for about $45 \%$ of overall exports (see Figure 3). Works by Bhagwati (1984); Hindley and Smith (1984); Deardorff (1985); Francois (1990); Sapir and Winter (1994); Adlung and Mattoo (2008); Francois and Hoekman (2010); Goswami, Mattoo, and Sáez (2012); and Hoekman (2018) have proved that services are tradable. Albeit by adjusting goodsspecific international trade theories (such as the Classics), since services-specific theories are underdeveloped. Discussions on trade in services are often absent in HET discussions, but it is imperative to introduce them as we have done in this study.

At the same time, trade barriers have been applied in this regime. These are tariffs and non-tariff barriers for goods (ROK, 2017) and regulations for services (Balistreri et al., 2009; 2015). These are pre-classical practices of Mercantilists and Older Historical School, especially Friedrich List, who advocated for import restriction.

Figure 3. Share of Goods and Services in Total Exports in Kenya (1975-2017)

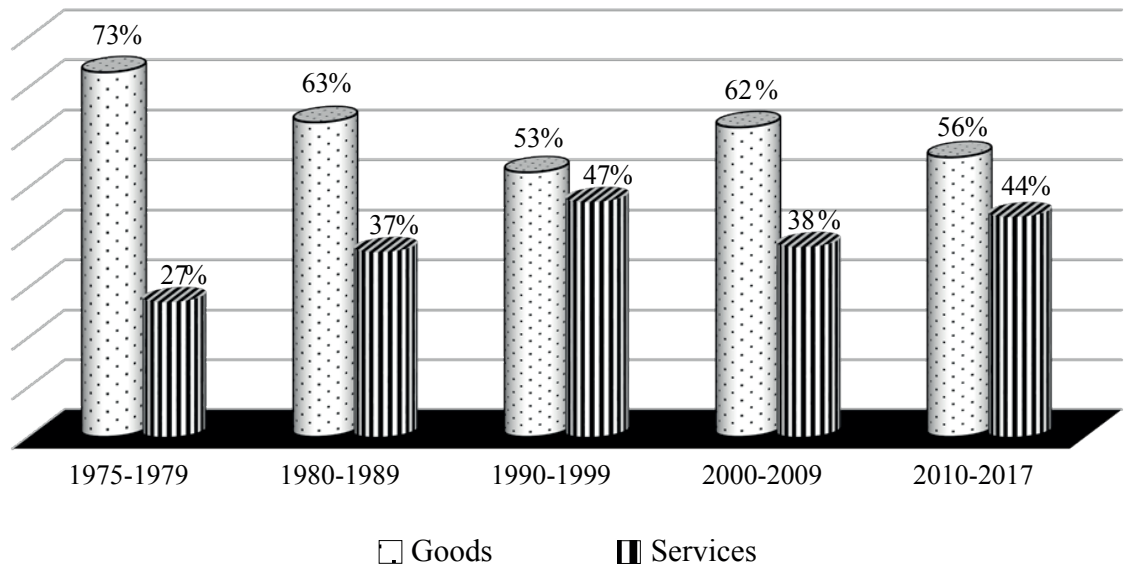

Source: Own computation from World Bank (2019) data.

2 Services are defined using four modes (Adlung \& Mattoo, 2008), but a fifth mode is under consideration (Cernat \& Kutlina-Dimitrova, 2014). Mode 1 is on cross-border services, Mode 2 is consumption abroad, Mode 3 is commercial presence, Mode 4 is on movement of natural persons, and Mode 5 is on intermediate service inputs. 


\section{CONCLUSION}

This study sought to show the pragmatic side of the History of Economic Thought using trade reforms in Kenya. Through it, we have linked trade practices and policies from the pre-colonial, colonial, and post-colonial periods to the respective schools of economic thought. The pre-colonial period, which existed before Kenya was declared a British Protectorate in 1895, had a mixture of classical and pre-classical doctrines. Classicism was practiced through long-distance and barter inter-community trade, where regions exchanged commodities, either by considering their absolute advantage or comparative advantage. Mercantilism was also evident where communities wanted to acquire wealth from trading at the expense of other communities. Nevertheless, the direction of trade was disrupted with the invasion of Europeans in the sixteenth and seventeenth century. They adhered to Classical canons by taking labor in form of slaves from Africa to their country. This was meant to facilitate the industrial revolution. They also practiced mercantilism by building strong nations with the increase of the stock of wealth of the nations by obtaining precious silver, gold, and other metals from the African nations.

The colonial period lasted between 1895 and 1962. Based on the Berlin conference of 1884-1885, Kenya was declared part of 'Africa of the labor reserves' (Nzula et al., 1979; Amin, 1972). Whereas, no clear trade policy existed, like the pre-colonial period, international trade was practiced. Local agricultural produce was exported, and less expensive consumables were imported. This was in line with the Classical sentiments of Smith and Ricardo. However, it was discriminatory as Africans were sidelined to domestic trade, while Asians and Europeans engaged in international trade.

The post-independence period, after 1963, had clear trade policies. First, an import substitution policy was adopted between 1963 and 1979. This policy was Mercantilist and to some extent Marxist because it restricted imports and encouraged nationalism. Nevertheless, a little international trade was allowed through joining two trade agreements: GATT and EAC. This regime was followed by SAPs, which lasted between 1980 and 1992. SAPs advocated for privatization, which can be likened to Physiocratic and Classical doctrines of the laissez faire. Both imports and exports were promoted under this policy. The third regime coincided with the liberalization of Kenya's economy in 1993 (Wacziarg \& Welch, 2008). This policy lasted between 1993 and 2002 and it was guided by the Sixth Development Plan (1989-1993). Under this policy, key institutions were formed to promote trade. The country also joined more trade agreements such as WTO in 1995. This trend continued to the fourth regime, which lasted between 2003 and 2007 and it was 
guided by the Economic Recovery Strategy for Wealth and Employment Creation (ERS). These are Classical doctrines.

The latest trade policy has lasted from 2008 to date. It is guided by two documents, the Vision 2030 and the National Trade Policy of 2017. Under this regime, trade has been barred and promoted. Meaning that both Pre-classical and Classical measures have been applied. The regime has also contributed towards trade in services. For a long time, services were perceived as non-tradable, but recent evidence shows that it is possible to export and import services, even in Kenya. This discussion is often absent in the History of Economic Thought.

We hope that more researchers will be motivated by our work to explain contemporary global problems from a History of Economic Thought perspective. For instance, structural transformation (Rodrik, 2016) and general economic thought of less researched regions such as Africa, Asia and Latin America. The economic thought of women is also less studied besides attempts by Madden and Dimand (2019) and papers in the Journal of Feminist Economics.

\section{REFERENCES}

Adlung, R., \& Mattoo, A. (2008). A framework of trade in services: The GATS. In A. Mattoo, R. M. Stern, \& G. Zanini (Eds.), A Handbook of International Trade in Services (pp. 48-83). Oxford, United Kingdom: Oxford University Press.

Amin, S. (1972). Underdevelopment and dependence in black Africa: Historical origin. Journal of peace research, 9(2), 105-119.

Aspromourgos, T. (2017). Why history of economics? History of Economics Review, 67(1), 59-69.

Balistreri, E. J., Jensen, J., \& Tarr, D. (2015). What determines whether preferential liberalization of barriers against foreign investors in services are beneficial or immizerising: Application to the case of Kenya. Economics: The Open-Access, Open-Assessment E-Journal, 9(42), 1-134.

Balistreri, E. J., Rutherford, T. F., \& Tarr, D. G. (2009). Modeling services liberalization: The case of Kenya. Economic Modelling, 26(3), 668-679.

Beal, D., Guizzo, D., \& Cruz e Silva, V. (2019). Macroeconomics, development economics, and biographical topics: Two years in the history of economic thought (2016-2017). History of Economic Ideas, 27(2), 163-196.

Bernard, A. B., \& Jensen, J. B. (1995). Exporters, jobs, and wages in US manufacturing: 1976-1987. Brookings Papers on Economic Activity. Microeconomics, 67-112. 
Bernard, A. B., \& Jensen, J. B. (1999). Exceptional exporter performance: cause, effect, or both? Journal of International Economics, 47(1), 1-25.

Bernard, A. B., \& Moxnes, A. (2018). Networks and trade. Annual Review of Economics, 10, 65-85.

Bernard, A. B., Jensen, J. B., Redding, S. J., \& Schott, P. K. (2012). The empirics of firm heterogeneity and international trade. Annual Review of Economics, 4(1), 283-313.

Bernard, A., \& Jensen, B. (2004). Why some firms export. Review of Economics and Statistics, 86(2), 561-569.

Bernard, A., Eaton, J., Jensen, J., \& Kortum, S. (2003). Plants and productivity in international trade. American Economic Review, 93(4), 1268-1290.

Bhagwati, J. N. (1984). Splintering and disembodiment of services and developing nations. The World Economy, 7(2), 133-144.

Bianchi, G. (2016). Annual survey of ideas in history of economic thought journals (2014-2015). History of Economic Ideas, 24(1), 115-141.

Blaug, M. (2001). No history of ideas, please, we're economists. Journal of Economic Perspectives, 15(1), 145-164.

Bögenhold, D. (2020). History of economic thought as an analytic tool: Why past intellectual ideas must be acknowledged as lighthouses for the future. International Advances in Economic Research, 26, 73-87. Retrieved from https:// doi.org/10.1007/s11294-020-09775-3

Brander, J., \& Krugman, P. (1983). A 'reciprocal dumping'model of international trade. Journal of International Economics, 15(3-4), 313-321.

Castellani, D., Damijan, J., \& Kostevc, Č. (2020). What makes a successful exporter? An introduction. The World Economy, 43(5), 1148-1150.

Cernat, L., \& Kutlina-Dimitrova, Z. (2014). Thinking in a box: A 'mode 5' approach to service trade. Journal of World Trade, 48(6), 1109-1126.

Coulomb, F., \& Bellais, R. (2008). The marxist analysis of war and military expenditures, between certainty and uncertainty. Defence and Peace Economics, 19(5), 351-359.

Deardorff, A. V. (1985). Comparative advantage and international trade and investment in services. In R. M. Stern, \& R. Stern (Eds.), Trade and Investment in Services: Canada/US Perspectives (pp. 39-71). Toronto: Ontario Economic Council.

Dillard, D. (1988). The barter illusion in classical and neoclassical economics. Eastern Economic Journal, 14(4), 299-318.

Dixit, A. K., \& Stiglitz, J. E. (1977). Monopolistic competition and optimum product diversity. The American Economic Review, 67(3), 297-308.

Duarte, P. G., \& Giraud, Y. (2016). The place of the history of economic thought in mainstream economics, 1991-2011, viewed through a bibliographic survey. Journal of the History of Economic Thought, 38(4), 431-462. 
Ethier, W. J. (1982). National and international returns to scale in the modern theory of international trade. The American Economic Review, 72(3), 389-405.

Falvey, R. E. (1981). Commercial policy and intra-industry trade. Journal of International Economics, 11(4), 495-511.

Francois, J. F. (1990). Trade in nontradables: Proximity requirements and the pattern of trade in services. Journal of International Economic Integration, 5(1), 31-46.

Francois, J., \& Hoekman, B. (2010). Services trade and policy. Journal of Economic Literature, 48(3), 642-692.

Geda, A. (2012). Fundamentals of International Economics for Developing Countries: A Focus on Africa. Nairobi, Kenya: African Economic Research Consortium.

Geda, A., \& Yimer, A. (2019, December 11). The Trade Effects of the African Continental Free Trade Area (AfCFTA): An Empirical Analysis. Retrieved from https://www.researchgate.net/publication/337733333_The_Trade_Effects of_the_African_Continental_Free_Trade_Area_AfCFTA_An_Empirical Analysis

Gertz, G. (2008). Kenya's Trade Liberalization of the 1980s and 1990s: Policies, Impacts, and Iimplications. Washington D.C.: Carnegie Endowment for International Peace.

Goswami, A. G., Mattoo, A., \& Sáez, S. (2012). Exporting Services: A Developing Country Perspective. Washington DC: The World Bank.

Gruber, W., Mehta, D., \& Vernon, R. (1967). The R\&D factor in international trade and international investment of United States industries. Journal of Political Economy, 75(1), 20-37.

Guizzo, D. (2020). Why does the history of economic thought neglect Post-Keynesian economics? Review of Keynesian Economics, 8(1), 119-137.

Head, K., \& Spencer, B. J. (2017). Oligopoly in international trade: Rise, fall and resurgence. Canadian Journal of Economics, 50(5), 1414-1444.

Helpman, E. (1981). International trade in the presence of product differentiation, economies of scale and monopolistic competition: A Chamberlin-Heckscher-Ohlin approach. Journal of International Economics, 11(3), 305-340.

Henry, J. F. (2008). The ideology of the laissez faire program. Journal of Economic Issues, 42(1), 209-224.

Herlehy, T. (1984). Ties that bind: Palm wine and blood-brotherhood at the Kenya coast during the 19th century. The International Journal of African Historical Studies, 17(2), 285-308.

Hindley, B., \& Smith, A. (1984). Comparative advantage and trade in services. The World Economy, 7(4), 369-390.

Hoekman, B. (2018). Trade in services: Opening markets to create opportunities. In R. S. Newfarmer, J. Page, \& F. Tarp (Eds.), Industries without Smokestacks: Industrialization in Africa Reconsidered (pp. 151-169). Oxford, UK: Oxford University Press. 
Kates, S. (2013). Defending the History of Economic Thought. Cheltenham, UK: Edward Elgar.

Krugman, P. (1991). Increasing returns and economic geography. Journal of Political Economy, 99(3), 483-499.

Krugman, P. R. (1979). Increasing returns, monopolistic competition, and international trade. Journal of International Economics, 9(4), 469-479.

Krugman, P. R. (1980). Scale economies, product differentiation, and the pattern of trade. American Economic Review, 70(5), 950-959.

Kurz, H. D. (2006). Whither the history of economic thought? Going nowhere rather slowly? The European Journal of the History of Economic Thought, 13(4), 463-488.

Lancaster, K. (1980). Intra-industry trade under perfect monopolistic competition. Journal of International Economics, 10(2), 151-175.

Lancaster, K. J. (1966). A new approach to consumer theory. Journal of Political Economy, 74(2), 132-157.

Landreth, H., \& Colander, D. C. (2002). History of Economic Thought (4th ed). Boston: Houghton Mifflin Company.

Lange, J., Svorencík, A., \& Schumacher, R. (2017). From antiquity to modern macro: An overview of contemporary scholarship in the history of economic thought journals, 2015-2016. History of Economic Ideas, 25(2), 172-207.

Lapidus, A. (2019). Bringing them alive. The European Journal of the History of Economic Thought, 26(6), 2019.

Loungani, P., Mishra, S., Papageorgiou, C., \& Wang, K. (2017). World Trade in Services: Evidence from A New Dataset. (Working Paper No. 17/77). Washington: International Monetary Fund.

Madden, K., \& Dimand, R. W. (2019). The Routledge Handbook of the History of Women's Economic Thought. New York: Routledge.

Melitz, M. (2003). The Impact of Trade on Intra-Industry Reallocations and Aggregate Industry Productivity. Econometrica, 71(6), 1695-1725.

Melitz, M., \& Redding, S. (2014). Heterogeneous firms and trade. In G. Gopinath, E. Helpman, \& K. Rogoff (Eds.), Handbook of International Economics (pp. 1-54). New York: Elsevier.

Moradi, A. (2018). Sub-Saharan Africa. In M. Blum, C. L. Colvin, M. Blum, \& C. L. Colvin (Eds.), An Economist's Guide to Economic History (pp. 285-292). Cham, Switzerland: Palgrave Macmillan.

Ndege, P. O. (1992a). Internal trade in Kenya, 1895-1963. In W. R. Ochieng, R. M. Maxon, W. R. Ochieng, \& R. M. Maxon (Eds.), An Economic History of Kenya (pp. 201-222). Nairobi, Kenya: East African Education Publishers Ltd. Ndege, P. O. (1992b). Kenya's foreign trade, 1895-1963. In W. R. Ochieng, R. M. Maxon, W. R. Ochieng, \& R. M. Maxon (Eds.), An Economic History of 
Kenya (pp. 223-248). Nairobi, Kenya: East African Educational Publishers Ltd.

Neary, P. (2010). Two and a half theories of trade. The World Economy, 33(1), 1-19. Nyaga, N. G. (2015). The evolution of Kenya's trade policy. Indian Journal of Economics and Development, 3(1), 120-126.

Nzula, A. T., Potekhin, I. I., \& Zusmanovich, A. Z. (1979). Forced Labour in Colonial Africa. London: Zed Press.

Obeng-Odoom, F. (2020). The African continental free trade area. American Journal of Economics and Sociology, 79(1), 167-197.

Omolo, M. W. (2011). The Impact of Trade Liberalization on Poverty in Kenya. Nairobi: Institute of Economic Affairs.

Posner, M. V. (1961). International trade and technical change. Oxford Economic Papers, 13(3), 323-341.

Redding, S. J. (2011). Theories of heterogeneous firms and trade. Annual Review of Economics, 3(1), 77-105.

Ricardo, D. (1817). On the Principles of Political Economy and Taxation. Kitchener, Ontario: Batoche Books.

Rodrik, D. (2016). Premature deindustrialization. Journal of Economic Growth, 21(1), 1-33.

ROK. (2007). Kenya Vision 2030. Nairobi, Kenya: Government Printers.

ROK. (2017). National Trade Policy: Transforming Kenya into a Competitive ExportLed and Efficient Domestic Economy. Nairobi: Government Printers.

Sapir, A., \& Winter, C. (1994). Services trade. In D. Greenaway, A. L. Winters, D. Greenaway, \& A. L. Winters (Eds.), Surveys in International Trade (pp. 273-302). Cambridge, Mass. and Oxford: Blackwell.

Sauvé, P., \& Roy, M. (2016). Research Handbook on Trade in Services. Cheltenham, UK: Edward Elgar Publishing Limited.

Schumacher, R. (2012). Adam Smith's theory of absolute advantage and the use of doxography in the history of economics. Erasmus Journal for Philosophy and Economics, 5(2), 54-80.

Skinner, A. S. (1993). David Hume: Principles of political economy. In D. F. Norton, \& D. F. Norton (Eds.), The Cambridge Comapanion to Hume (pp. 222- 254). Cambridge: Cambridge University Press.

Smith, A. (1776). An Inquiry into the Nature and Causes of the Wealth of Nations. New York: Modern Library.

Strange, G. (2020). Debating free international trade. American Journal of Economics and Sociology, 79(1), 25-47.

Van Zwanenberg, R. M., \& King, A. (1975). An Economic History of Kenya and Uganda, 1800-1970. London, UK: Macmillan Press Ltd. 
Vernon, R. (1966). International investment and international trade in the product cycle. The Quarterly Journal of Economics, 80(2), 190-207.

Wacziarg, R., \& Welch, K. H. (2008). Trade liberalization and growth: New evidence. The World Bank Economic Review, 22(2), 187-231.

Wagner, J. (2016). A survey of empirical studies using transaction level data on exports and imports. Review of World Economics, 152(1), 215-225.

Walter, D. A. (1996). Adam Smith and the liberal tradition in international relations. Review of International Studies, 22(1), 5-28.

Were, M., Ndung'u, N. S., Geda, A., \& Karingi, S. N. (2002). Analysis of Kenya's Export Performance: An Empirical Evaluation. (KIPPRA, Discussion Paper No. 22). Retrieved from https://waleolusi.files.wordpress.com/2013/05/analysis-of-kenyas-export-performance-an-empiricall.pdf

Yeaple, S. R. (2005). A simple model of firm heterogeneity, international trade, and wages. Journal of International Economics, 65(1), 1-20.

(C) 2021 por los autores; licencia no exclusiva otorgada a la revista Estudios económicos. Este artículo es de acceso abierto y distribuido bajo los términos y condiciones de una licencia Atribución-No Comercial 4.0 Internacional (CC BY-NC 4.0) de Creative Commons. Para ver una copia de esta licencia, visite http://creativecommons.org/licenses/by-nc/4.0 
